\title{
Association between workload of the nursing staff and patient safety outcomes
}

\author{
Associação entre carga de trabalho da equipe de enfermagem e \\ resultados de segurança do paciente
}

\author{
Asociación entre carga de trabajo del equipo de enfermería \\ y resultados de seguridad del paciente
}

\begin{abstract}
Ana Maria Müller de Magalhães ${ }^{1}$, Diovane Ghignatti da Costa ${ }^{2}$, Caren de Oliveira Riboldi ${ }^{3}$, Thiane Mergen ${ }^{3}$, Amanda da Silveira Barbosa ${ }^{1}$, Gisela Maria Schebella Souto de Moura ${ }^{1}$
\end{abstract}

How to cite this article:

Magalhães AMM, Costa DG, Riboldi CO, Mergen T, Barbosa AS, Moura GMSS. Association between workload of the nursing staff and patient safety outcomes. Rev Esc Enferm USP. 2017;51:e03255. DOI: http://dx.doi.org/10.1590/S1980-220X2016021203255

\author{
${ }^{1}$ Universidade Federal do Rio Grande do Sul, \\ Escola de Enfermagem, Porto Alegre, RS, Brazil \\ ${ }^{2}$ Universidade Federal do Rio Grande \\ do Sul, Programa de Pós-Graduação em \\ Enfermagem, Porto Alegre, RS, Brazil. \\ ${ }^{3}$ Hospital de Clínicas de Porto \\ Alegre, Porto Alegre, RS, Brazil.
}

\begin{abstract}
Objective: To describe the workload of the nursing team and relate it with patient safety outcomes in clinical and surgical inpatient units of a university hospital. Method: Crosssectional study, carried out from October 2013 to September 2015. The factor under study was the workload, expressed as the ratio between the mean number of patients and the number of nursing professionals in 24 hours and in the day shifts. Results: The sample consisted of 157,481 patients, 502 nursing professionals and 264 observations of safety outcomes. The ratios of patients per nurse and per nursing technician in day shifts indicate a mean estimate of 14-15 and 5-6 patients per professional, respectively. There was a significant association between the workloads in the inpatient units and average length of stay, urinary infection related to invasive procedure and the satisfaction of patients with nursing care. Conclusion: The increase in the workload of the nursing team had an impact on quality of care and safety for patients. An adequate staffing promotes a safer care environment.
\end{abstract}

\section{DESCRIPTORS}

Workload; Nursing, Team; Patient Safety; Nursing Staff, Hospital; Quality Indicators Health Care. 


\section{INTRODUCTION}

Patient safety is currently a recurring theme and a challenge for nursing and health services. Research in this field indicates that inadequate planning and staffing of nursing workers can have negative repercussions on the quality of care $^{(1-3)}$. Nursing managers still face difficulties to match the number of professionals with the demands of care, mainly due to budget allocation for hiring staff, even though an adequate staffing is recognized as important for a safe care practice ${ }^{(4-5)}$.

Despite growing evidence on the association between the workload of the nursing staff and patient safety in hospitals, there are still several gaps in the knowledge about this relation and its impact, addressing it as an isolated element or as a contributing factor to a good quality care. In this perspective, recent studies have shown that when nursing workload is high, nursing vigilance is impaired and there is an increase in the risk of adverse events such as falls, urinary tract infection, central catheter infection, medication administration errors, and others ${ }^{(1-5)}$.

Planning, nurse staffing and the organization of work processes should provide estimates of the number of professionals needed to provide care to a patient or a specific group of patients in general inpatient units. In this context, instruments that measure level of dependence or complexity of nursing care ${ }^{(6-7)}$ provide the necessary help to calculate the hours of nursing care required per patient day, in order to define the number of patients assigned to each nursing professional in the work shifts and support the delivery of care with quality and safety.

At an international level, research on the association between the workload of the nursing team and patient safety outcomes includes in the discussion the number of patients assigned to each nurse or nursing assistant and the conditions of the working environment ${ }^{(1,3-4,8-11)}$. In Brazil, there is still a long way to go before subsidizing the implementation of the minimum parameters for adequate staffing, as it is established by nursing official organizations in the country ${ }^{(12)}$ with the objective of balancing the number of patients per nursing professional in health institutions.

In this scenario, Brazilian studies addressing the theme have stressed the importance of an adequate number and a good qualification of the nursing staff in order to ensure patient safety ${ }^{(13-16)}$. However, in real life scenario, there are overcrowded hospitals, poor working conditions and a reduced number of nurses and nursing technicians, with only a few exceptions. These conditions are aggravated when the proportion between these professionals in the work scale does not meet the complexity of the nursing care required by the patients ${ }^{(12,16)}$.

Another important fact concerns the areas of care assessed in studies that address the relationship between hours of nursing care and patient safety. There is evidence that most of the research was conducted in intensive or specialized care, based on care and management quality indicators ${ }^{(2,13,15-17)}$, which makes it necessary to broaden the focus given to this phenomenon and specifically contemplate general inpatient units.
Several international studies ${ }^{(8,11,18-20)}$ indicate that efforts must be made to advance in this field and prevent the risks of adverse events and errors in health care systems. The results of these studies highlight the importance of new research to evaluate the impacts of the nursing workload on the quality of care.

Considering the above, the present study aims to describe the workload of the nursing team and demonstrate its association with patient safety outcomes in clinical and surgical inpatient units of a university hospital.

\section{METHOD}

The data displayed are part of the results of an institutional project, aimed at assessing the factors that interfere in the workload of the nursing team and have repercussions on the safety of hospitalized patients. Thus, the present study describes the data gathered in the quantitative stage, which had a cross-sectional design and was conducted from October 2013 to September 2015, including 24 months of follow-up, reducing possible seasonal biases.

The study was conducted in a large university hospital, located in the city of Porto Alegre, in the south of Brazil, which works in a variety of specialties and is intended for patients of all age groups mostly arriving from the Unified Health System.

The population consisted of patients and professionals working in the 11 clinical and surgical units of the institution, which have 390 beds for adults. The sample was intentional and delimited by the investigation period and covered 157,481 patients and 502 nursing professionals, of whom 126 (25.1\%) were nurses and 376 (74.9\%) were nursing technicians. Professionals who were not part of the activities or did not appear as active in the work scales were excluded from the sample.

The sample also included 24 records of each variable analyzed monthly, making a sample $\mathrm{N}$ of 264 observations. The factor under study is the workload of the nursing team, which was monitored daily and described by the monthly mean.

The calculation of the workload of the nursing team was expressed as the ratio between the mean number of patients and the mean number of professionals working in the 24 hours $(\mathrm{M}+\mathrm{A}+\mathrm{N})$ and for the day shifts, considering only the sum of professionals in the morning and afternoon shifts $(M+A)$, divided into the categories nurse and nursing technician.

For the calculation of the ratio of patient per nurse and nursing technician, the number of nursing professionals working from Monday to Friday was considered, excluding holidays and weekends. Therefore, it was possible to compare results with those from international literature, which also presents findings regarding day shifts of nursing workers.

The data from the professionals were collected prospectively, directly in the inpatient units, with the daily filling of a spreadsheet by checking the scales and confirming with the nurses the number of professionals working in each shift. Patient data were collected through the institution's 
Management Information System, based on the monthly reports of indicators in each unit.

The outcomes assessed as indicators of quality and safety of care were mean length of stay, incidence of falls (IF), incidence of pressure ulcer $(\mathrm{PU})$, urinary tract infection related to invasive procedure (UTI), primary bloodstream infection (BSI), besides the indicators of quality and safety management considered, that is, absenteeism, turnover and level of satisfaction with the care received. These indicators were defined based on research on the subject and on previous studies in the same field ${ }^{(4,5,8,11,21)}$.

The data were organized in a Microsoft Excel ${ }^{\circledR}$ spreadsheet and imported into the Statistical Package for Social Sciences (SPSS/PASW) version 18.0. The analysis was descriptive and analytical and was conducted using Generalized Estimating Equations (GEE) and one-way ANOVA and included the assistance of a professional statistician. A 95\% confidence interval was set and a two-tailed $P$ value of 0.05 or less was considered statistically significant.
The study complied with the recommendations of Resolution 466/12 of the National Health Council (CONEP) and was approved by the Research Ethics Committee of the institution under the number 120332.

\section{RESULTS}

The characterization data of the inpatient units indicated a bed occupancy rate of 86.23 , with standard deviation (SD) of 11.23 and mean of 31.25 patients (SD 11.57).

The ratio of patients per nurse and per nurse technician, in the 24 hours and during day shifts $(M+A)$, is described in Table 1, along with the results of the quality and safety indicators related to care and to management. The general data on the inpatient units in day shifts $(M+A)$ indicate a mean estimate of $14-15$ patients per nurse and 5-6 patients per nursing technician, considering that patients are present in both shifts and the data of the professionals consider the sum of nurses and nursing technicians in the morning and afternoon shifts.

Table 1 - Workload indicators and patient safety outcomes related to management and care - Porto Alegre, Rio Grande do Sul, Brazil, Oct. 2013 to Sept. 2015.

\begin{tabular}{|c|c|c|c|c|c|}
\hline Quality and Safety Indicators ( $\mathrm{n}=\mathbf{2 6 4})$ & Mean & $\begin{array}{l}\text { Standard } \\
\text { Deviation }\end{array}$ & Median & \multicolumn{2}{|c|}{ P25 - P75* } \\
\hline \multicolumn{6}{|l|}{ Workload of nursing staff } \\
\hline Patient/nurse in the $24 \mathrm{~h}$ & 4.96 & 1.08 & & & \\
\hline Patient/nursing technician in the $24 \mathrm{~h}$ & 1.63 & 0.23 & & & \\
\hline Patient/nurse in day shifts $(M+A)$ & 6.89 & 1.69 & & & \\
\hline Patient/nursing technician in day shifts $(M+A)$ & 2.26 & 0.34 & & & \\
\hline \multicolumn{6}{|l|}{ Patient safety outcomes related to care } \\
\hline Mean length of stay & 8.18 & 2.52 & & & \\
\hline Incidence of falls (IF) & & & 1.53 & 0.73 & -2.42 \\
\hline Incidence of Pressure Ulcer (PU) & & & 0.00 & 0 & -1.17 \\
\hline Urinary tract infection related to invasive procedures (UTI) & & & 2.99 & 0 & -8.13 \\
\hline Primary bloodstream infection (BSI) & & & 0.00 & 0 & -4.48 \\
\hline \multicolumn{6}{|l|}{ Patient safety outcomes related to management } \\
\hline Absenteeism & & & 3.21 & 2.12 & 4.42 \\
\hline Turnover & & & 0.00 & 0 & 0.88 \\
\hline Patients' level of satisfaction with the nursing team (\%) & 77.90 & 10.44 & & & \\
\hline
\end{tabular}

Note: ${ }^{*} 25$ percentile; 75 percentile.

The ratios of patients per nurse and per nursing technician in day shifts showed statistically significant difference ( $p<0.01$ ) between different inpatient units, based on the one-way ANOVA.

The lowest mean of the workload indicator for nurses was 4.02 (SD 0.40) and the highest was 8.59 (SD 0.97), representing an estimate of $7-8$ and $17-18$ patients per nurse in the morning or afternoon shifts, respectively. In relation to nursing technicians, the lowest mean of the workload indicator was 1.79 (SD 0.18) and the highest was 2.66 (SD 0.22 ), representing an estimate of 4 and 5-6 patients per nursing technician in the morning or afternoon shifts. These results are observed in Figure 1.

The results of the GEE analysis demonstrated a significant association between the workloads in the inpatient units and the mean length of stay, urinary tract infection related to invasive procedure and the satisfaction of patients with the nursing care, as shown in Table 2.

The results indicate that higher workloads, that is, the number of patients assigned to nurses and nursing technicians in the 24 hours and in the day shifts $(M+A)$, are related to longer hospital stays and higher incidence of urinary tract infection related to invasive procedures. Also, an inverse significant association $(p<0.01)$ was observed between workload and level of satisfaction with the care given by the nursing staff, meaning that higher numbers of patients assigned to nurses and nursing technicians result in lower satisfaction with the care received. The turnover had a significant association with the nurses' workload in the 24 hours $(\mathrm{p}<0.04)$. 


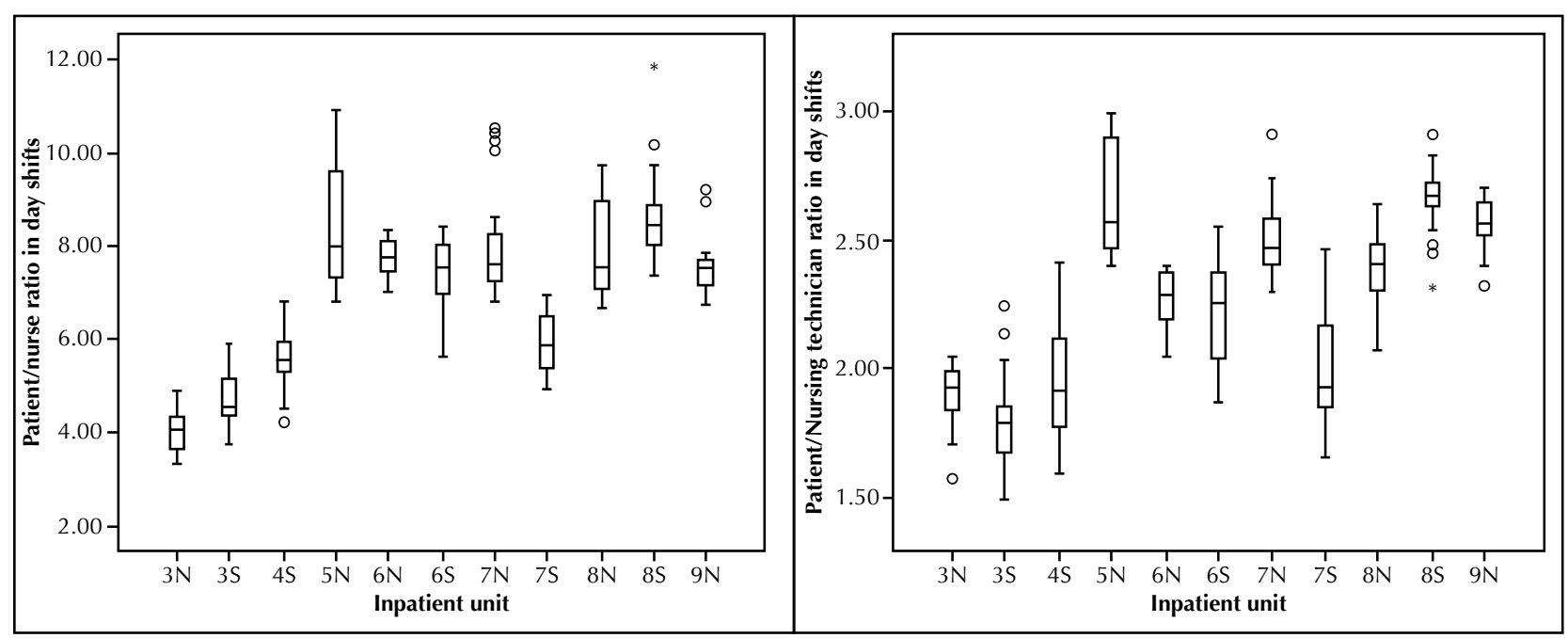

Figure 1 - Distribution of ratios of patients per nurse and per nursing technician in day shifts (M+A) - Porto Alegre, Rio Grande do Sul, Brazil, Oct. 2013 to Sept. 2015.

Table 2 - Association between management and care quality indicators related to patient safety and workload of the nursing staff Porto Alegre, Rio Grande do Sul, Brazil, 2015.

\begin{tabular}{|c|c|c|c|c|c|c|c|c|}
\hline \multirow[t]{2}{*}{ Quality and Safety Indicators } & \multicolumn{2}{|c|}{$\begin{array}{l}\text { Patient/ } \\
\text { Nurse 24h }\end{array}$} & \multicolumn{2}{|c|}{$\begin{array}{c}\text { Patient/ } \\
\text { Nurse } \\
\text { Day Shift }\end{array}$} & \multicolumn{2}{|c|}{$\begin{array}{c}\text { Patient/ } \\
\text { Nursing Technician } \\
24 \mathrm{~h} \\
\end{array}$} & \multicolumn{2}{|c|}{$\begin{array}{c}\text { Patient/ } \\
\text { Nursing Technician } \\
\text { Day Shift }\end{array}$} \\
\hline & $\mathbf{B}^{+}$ & $\mathbf{P}$ & $\mathbf{B}^{+}$ & $\mathbf{P}$ & $\mathbf{B}^{+}$ & $\mathbf{P}$ & $\mathbf{B}^{+}$ & $\mathbf{P}$ \\
\hline \multicolumn{9}{|l|}{ Care } \\
\hline Mean lenght of stay & 0.65 & 0.00 & 0.34 & 0.00 & 3.44 & 0.00 & 2.28 & 0.00 \\
\hline Incidence of falls (IF) & 0.00 & 0.96 & 0.02 & 0.71 & 0.12 & 0.67 & 0.19 & 0.32 \\
\hline Incidence of pressure ulcer (PU) & -0.08 & 0.39 & -0.05 & 0.43 & -0.34 & 0.44 & -0.21 & 0.46 \\
\hline Urinary tract infection related to invasive procedures (UTI) & 0.23 & 0.00 & 0.16 & 0.00 & 1.26 & 0.00 & 0.80 & 0.00 \\
\hline Primary bloodstream infection (BSI) & -0.08 & 0.52 & -0.05 & 0.55 & -0.61 & 0.39 & -0.43 & 0.41 \\
\hline \multicolumn{9}{|l|}{ Management } \\
\hline Absenteeism & 0.12 & 0.38 & 0.15 & 0.07 & 0.49 & 0.42 & -0.28 & 0.52 \\
\hline Turnover & 0.20 & 0.04 & 0.13 & 0.06 & 0.61 & 0.24 & 0.39 & 0.24 \\
\hline Level of satisfaction with the nursing team & -2.61 & 0.00 & -1.63 & 0.00 & -8.84 & 0.00 & -5.67 & 0.00 \\
\hline
\end{tabular}

$\mathrm{B} \dagger$ Generalized Estimating Equations describe the association between the factor under study and the outcomes. Associations were significant if $\mathrm{P}<0.05$.

\section{DISCUSSION}

The description of the nursing workload, defined in this study as the ratio between patients and nursing professionals in the 24 hours and day shifts $(\mathrm{M}+\mathrm{A})$, allowed finding statistically significant differences $(p<0.01)$ between the units assessed. The data presented evidences that the ratios of patient per nurse in the day shifts ranged from 4.02 (SD 0.40 ) to 8.59 (SD 0.97) and the ratios of patient per nursing technician ranged from 1.79 (SD 0.18) to 2.66 (SD 0.22) in the units of the institution assessed.

The mean numbers of 4.96 (SD 1.08) patients per nurse and 1.63 (SD 0.23) patients per nursing technician in the 24 hours show that there was an increase in the nursing staff in these units, since data of a previous research, carried out in a similar set of units, identified a mean ratio of 6.44 (SD 2.01) patients per nurse in the 24 hours and 1.82 (SD 0.33) patients per nursing technician. Smaller ratios indicate fewer patients assigned to nursing professionals ${ }^{(5)}$.
The significant variation found regarding the number of patients per nurse in the units assessed are consistent with data from an Australian study ${ }^{(8)}$. This study used cross-sectional and longitudinal designs in 80 and 286, respectively, general inpatient units and found a variation of 6.14 to 9.90 patients per nursing professional in the 24 hours, considering all the nursing categories and with a mean number of 7.99 (SD 2.31) patients per registered nurse in the 24 hours.

A cross-sectional study conducted in 12 European countries calculated the number of nurses in each hospital and the ratio of patients per nurse in each unit based on information from each nurse's last shift, assessed through survey. Using the practice environment scale of the nursing work index (PES-NWI), this study found a mean of patients per nurse in the hospitals (in all shifts) ranging from 5.4 in Norway to 13.0 in Germany, and a mean number of patients per total number of professionals ranging from 3.3 in Norway to 10.5 in Germany ${ }^{(4)}$. 
In the United States, a study conducted in 617 hospitals ${ }^{(4)}$ found a mean number of 5.3 patients per registered nurse and 3.6 patients per total number of nursing professionals. In England ${ }^{(20)}$ a mean of 7.97 patients per registered nurse was found in clinical units, with a minimum of 4.85 and a maximum of 11.06 patients, while in surgical units a mean of 7.33 patients per registered nurse was found, with a minimum of 4.60 and a maximum of 11.34 patients.

Considering that these studies indicate the mean number of patients per nurses in typical shifts in the inpatient units, the present study found units with numbers similar to the international data, such as 7-8 patients per nurse, and other units with means higher than international data, such as 17-18 patients per nurse per shift.

Considering that the inpatient units assessed in this study are part of the same institution and have similar levels of dependence of the patients and similar structure, these differences in the proportions of patients per nurse and per nursing technician can demonstrate the impact of the workload of nursing staff on quality and safety outcomes for patients. This is proved true by the association between the workload of the nursing staff in these units and some of the quality of care indicators. In the units with higher number of patients assigned to nursing professionals there was an increase in the patients' mean length of stay $(B=0.65$ / 0.34/ 3.44/ 2.28; $\mathrm{p}<0.01)$ and in the incidence of urinary tract infections related to invasive procedures $(B=0.23 / 0.16 / 1.26 / 0.80 ; p<0.01)$.

These results are consistent with the findings of other studies $^{(1,8,18-19,22)}$, which indicate that better nurse staffing and the consequent increase in nursing hours for the patient have significant association $(\mathrm{p}<0.01)$ with lower rates of pressure ulcers, pneumonia, falls and sepsis, as well as with a reduction in medication errors and mortality. Thus, it is understood that the increase in the number of patients assigned to nurses is associated with negative quality and safety outcomes for hospitalized patients.

A study conducted in England demonstrated that hospitals that presented a mean of six patients or less per registered nurse in clinical units had a $20 \%$ lower mortality rate when compared to hospitals with 10 patients or more per nurse (RR 0.80, 95\% CI 0.76-0.85, p<0.01) ${ }^{(20)}$.

Likewise, the inverse significant association $(\mathrm{p}<0.01)$ found between the workload and the level of satisfaction of the patients with the care received by the nursing team is consistent with the results of other studies, which indicated that higher numbers of patients assigned to the nursing team decrease patient satisfaction and that the restriction or reduction of nursing staff has a negative repercussion on patients' and professionals' perception of safety in care environments ${ }^{(4-5,23-24)}$.

Despite the differences in context, working hours, professional training and others, studies in different countries indicated that the increase in the number of nurses and nursing hours in patient care, as well as a higher proportion of nurses in teams composed also by professionals with a vocational education can improve quality and safety outcomes for patients in hospitals.

This study indicated that $25.1 \%$ of the nursing staff in clinical and surgical inpatient units are nurses, a result consistent with the survey of the socio-demographic profile of nursing in Brazil, which found that only $23 \%$ of the nursing workforce in our country is composed of nurses, that is, professionals with a Bachelor`s degree. These results are comparable to registered nurses in other countries ${ }^{(25)}$.

These data can be considered concerning when compared to other countries with a much higher proportion of nurses in the nursing team, such as presented in a study conducted in Australia, where $68.4 \%$ of nursing professionals in clinical and surgical units were registered nurses ${ }^{(8)}$. In European countries, the data found showed a variation of registered nurses in inpatient units ranging from $54 \%$ in Spain to $82 \%$ in Germany ${ }^{(26)}$.

Recent research in European countries concluded that bedside care workforce with a higher proportion of professional nurses was associated with better patient outcomes and better working and safety conditions at the hospitals ${ }^{(22)}$. However, despite the growing evidence on the causal relationship between nurse staffing and better outcomes for the patients, the findings are still inconsistent when regarding the financial aspects involved in the adoption of policies for adequate nurse staffing in practice scenarios, both in international and Brazilian contexts. This is an indication for the necessity of development of further research on the costs and financial impacts of the nursing workforce on quality and safety outcomes ${ }^{(27-28)}$.

Although the results of this study are supported by a large quantitative data collection, it was necessary to focus on the typical day shifts in order to study the phenomenon, as it was described in the method. Thus, the workload of the night shifts and of teams working exclusively on weekends was not assessed, which may be a limitation of the study. Despite this, the evidence found by this research brings valuable contributions to the analysis and evaluation of nurse staffing and of potential risks to the safety of hospitalized patients. Since no studies were found to discuss these findings in national literature, new multicenter studies on the subject should be carried out, which would allow comparisons for Brazilian contexts.

\section{CONCLUSION}

The research on the workload of the nursing staff in the clinical and surgical inpatient units allowed us to identify the proportion of patients per nursing professional in the different work shifts. Significant differences were found between the workloads in these hospitalization units, both for nurses and for nursing technicians.

The data indicate that higher numbers of patients assigned to nursing professionals are associated with an increase in the mean length of stay and in urinary tract infections in these patients, outcomes considered negative for patient safety. The evaluation of the level of satisfaction of the patients with the care of the nursing team showed an inverse association with the workload, demonstrating that as the number of patients per professional increases, the satisfaction of patients with the care received decreases.

These findings reflect the importance of an adequate staffing distribution and a proper evaluation of the nursing staff workload, in order to provide a safer care environment with improved quality of care. 
RESUMO

Objetivo: Descrever a carga de trabalho da equipe de enfermagem e estabelecer associação com resultados de segurança do paciente em unidades de internação clínicas e cirúrgicas de um hospital universitário. Método: Estudo transversal, realizado de outubro de 2013 a setembro de 2015. O fator em estudo foi a carga de trabalho, expressa pela razão entre o número médio de pacientes e de profissionais de enfermagem em 24 horas e no período diurno. Resultados: A amostra abrangeu 157.481 pacientes, 502 profissionais de enfermagem e 264 observações dos resultados de segurança. As razões de pacientes por enfermeiro e técnico de enfermagem no diurno indicam uma estimativa média de 14-15 e 5-6 pacientes por profissional, respectivamente. Houve associação significativa entre as cargas de trabalho das unidades de internação e os resultados referentes à média de permanência hospitalar, à infecção urinária relacionada a procedimento invasivo e à satisfação de pacientes com o cuidado de enfermagem. Conclusão: $\mathrm{O}$ aumento da carga de trabalho da equipe de enfermagem teve impacto em resultados de qualidade da assistência e de segurança para os pacientes. A adequação do quadro de pessoal proporciona um ambiente de cuidado mais seguro.

\section{DESCRITORES}

Carga de Trabalho; Equipe de Enfermagem; Segurança do Paciente; Recursos Humanos de Enfermagem no Hospital; Indicadores de Qualidade em Assistência à Saúde.

\section{RESUMEN}

Objetivo: Describir la carga de trabajo del equipo de enfermería y establecer asociación con resultados de seguridad del paciente en unidades de estancia hospitalaria clínicas y quirúrgicas de un hospital universitario. Método: Estudio transversal llevado a cabo de octubre de 2013 a septiembre de 2015. El factor en estudio fue la carga de trabajo, expresada por la razón entre el número medio de pacientes y de profesionales de enfermería en 24 horas y en el período diurno. Resultados: La muestra comprendió a 157.481 pacientes, 502 profesionales de enfermería y 264 observaciones de los resultados de seguridad. Las razones de pacientes por enfermero y técnico de enfermería en el diurno señalan una estimación media de 14-15 y 5-6 pacientes por profesional, respectivamente. Hubo asociación significativa entre las cargas de trabajo de las unidades de hospitalización y los resultados referentes al promedio de permanencia hospitalaria, infección urinaria relacionada con procedimiento invasivo y la satisfacción de pacientes con el cuidado de enfermería. Conclusión: El aumento de la carga de trabajo del equipo de enfermería tuvo impacto en resultados de calidad de la asistencia y de seguridad para los pacientes. La adecuación del cuadro de personal proporciona un ambiente de cuidado más seguro.

\section{DESCRIPTORES}

Carga de Trabajo; Grupo de Enfermería; Seguridad del Paciente; Personal de Enfermería en Hospital; Indicadores de Calidad de la Atención de Salud.

\section{REFERENCES}

1. Needleman J, Buerhaus P, Pankratz S, Leibson CL, Stevens SR, Harris M. Nurse staffing and inpatient hospital mortality. N Engl J Med. 2011;364(11):1037-45.

2. Gonçalves LA, Andolhe R, Oliveira EM, Barbosa RL, Faro ACM, Gallotti RMD, et al. Nursing allocation and adverse events/incidents in intensive care units. Rev Esc Enferm USP [Internet]. 2012 [cited 2016 Jan 14];48(n.spe):71-7. Available from: http://www.scielo.br/pdf/ reeusp/v46nspe/en_11.pdf

3. Aiken LH, Cimiotti JP, Sloane DM, Smith HL, Flynn L, Neff DF. The effects of nurse staffing and nurse education on patient deaths in hospitals with different nurse work environments. Med Care. 2011;49(12):1047-53.

4. Aiken LH, Sermeus W, Heede KVd, Sloane DM, Busse R, McKee M, et al. Patient safety, satisfaction, and quality of hospital care: cross sectional surveys of nurses and patient in 12 countries in Europe and the United States. BM] [Internet]. 2012 [cited 2016 Jan 14];344:e1717. Available from: https://www.ncbi.nlm.nih.gov/pmc/articles/PMC3308724/

5. Magalhães AMM, Dall'Agnol CM, Marck PB. Nursing workload and patient safety: a mixed method study with an ecological restorative approach. Rev Latino Am Enfermagem [Internet]. 2013 [cited 2016 Jan 14];21(n.spe):146-54. Available from: http://www.scielo.br/pdf/ rlae/v21 nspe/19.pdf

6. Perroca MG. Development and content validity of the new version of a patient classification. Instrument. Rev Latino Am Enfermagem [Internet]. 2011 [cited 2016 Jan 14];19(1):58-66. Available from: http://www.scielo.br/pdf/rlae/v19n1/09.pdf

7. Perroca MG. The new version of a patient classification instrument: assessment of psychometrics properties. J Adv Nurs. 2013;69(8):1862-8.

8. Duffield C, Diers D, O'Brien-Pallas L, Aisbett C, Roche M, King M, et al. Nursing staffing, nursing workload, the work environment and patient outcomes. Appl Nurs Res. 2011;24(4):244-55.

9. Mark BA, Harless DW, Spetz J, ReiterKL, Pink GH. California's minimum nurse staffing legislation: results from a natural experiment. Health Serv Res. 2013; 48(2):435-53.

10. Ball JE, Murrells T, Rafferty AM, Morrow E, Griffiths P. 'Care left undone' during nursing shifts: associations with workload and perceived quality of care. BMJ Qual Saf. 2014;23(2):116-25.

11. Dubois CA, D'amour D, Tchouaket E, Clarke S, Rivard M, Blais R. Associations of patient safety outcomes with models of nursing care organization at unit level in hospitals. Int J Qual Health Care. 2013;25(2):110-7.

12. Conselho Federal de Enfermagem. Resolução COFEN-293, de 21 de Setembro de 2004. Fixa e estabelece parâmetros para o dimensionamento do quadro de profissionais de Enfermagem nas unidades assistenciais das instituições de saúde e assemelhados [Internet]. Brasília: COFEN; 2004 [citado 2016 jan. 14]. Disponível em: http://www.cofen.gov.br/resoluo-cofen-2932004_4329.html

13. Nogueira LS, Koike KM, Sardinha DS, Padilha KG, Souza RMC. Nursing workload in public and private intensive care units. Rev Bras Ter Intensiva. 2013;25(3):225-32. 
14. Trepichio PB, Guirardello EB, Duran ECM, Brito AP. Perfil dos pacientes e carga de trabalho de enfermagem na unidade de nefrologia. Rev Gaúcha Enferm [Internet]. 2013 [citado 2016 maio 03];34(2):133-9.

15. Novaretti MCZ, Santos EV, Quitério LM, Daud-Gallotti RM. Sobrecarga de trabalho da Enfermagem e incidentes e eventos adversos em pacientes internados em UTI. Rev Bras Enferm. 2014;67(5):692-9.

16. Fugulin FMT, Rossetti AC, Ricardo CM, Possari JF, Mello MC, Gaidzinski RR. Tempo de assistência de enfermagem em Unidade de Terapia Intensiva: avaliação dos parâmetros propostos pela Resolução COFEN n²293/04. Rev Latino Am Enfermagem. 2012;20(2):325-32.

17. Trettene AS, Luiz AG, Razera APR, Maximiano TO, Cintra FMRN, Monteiro LM. Nursing workload in specialized semi-intensive therapy unit: workforce size criteria. Rev Esc Enferm USP. 2015;49(6):958-63. DOI: http://dx.doi.org/10.1590/S0080-623420150000600012

18. Blegen MA, Goode CJ, Spetz J, Vaughn T, Park SH. Nurse staffing effects on patient outcomes: safety-net and non-safety-net hospitals. Med Care. 2011;49(4):406-14.

19. D'Amour D, Dubois C, Tchouaket E, Clarke S, Blais R. The occurrence of adverse events potentially attributable to nursing care in medical units: cross sectional record review. Int J Nurs Stud. 2014;51(6):882-91.

20. Griffiths P, Ball J, Murrells T, Jones S, Rafferty AM. Registered nurse, healthcare support worker, medical staffing levels and mortality in English hospital trusts: a cross-sectional study. BMJ Open [Internet] 2016 [cited 2016 May 03];6(2):e008751. Available from: http:// bmjopen.bmj.com/content/bmjopen/6/2/e008751.full.pdf

21. Monteiro LM, Spiri WC. Indicadores de qualidade e carga de trabalho uma revisão integrativa em enfermagem. REME Rev Min Enferm [Internet]. 2016 [citado 2016 nov. 29];20:e936. Disponível em: http://www.reme.org.br/artigo/detalhes/1070\#. DOI: 10.5935/14152762.20160006

22. Aiken LH, Sloane D, Griffiths P, Rafferty AM, Bruyneel L, McHugh M, et al. Nursing skill mix in European hospitals: cross-sectional study of the association with mortality, patient ratings, and quality of care. BM] Qual Saf [Internet]. 2016 [cited 2016 Nov 29];0. Available from: http://qualitysafety.bmj.com/content/qhc/early/2016/11/03/bmjqs-2016-005567.full.pdf

23. Papastavrou E, Andreou P, Tsangari H, Merkouris A. Linking patient satisfaction with nursing care: the case of care rationing - a correlational study. BMC Nurs [Internet]. 2014 [cited 2016 May 03];13:26. Available from: https://www.ncbi.nlm.nih.gov/pmc/articles/PMC4184047/

24. Alenius LS, Tishelman C, Runesdotter S. Staffing and resource adequacy strongly related to RNs' assessment of patient safety: a national study of RNs working in acute-care hospitals in Sweden. BM] Qual Saf [Internet] 2013 [cited 2016 Jan 14];23(3):241-9. Available from: https://www.ncbi.nlm.nih.gov/pmc/articles/PMC3932760/

25. Machado MH, Aguiar Filho W, Lacerda WF, Oliveira E, Lemos W, Wermelinger M, et al. Características gerais da enfermagem: o perfil sociodemográfico. Enferm Foco 2016;7(n.esp):9-14.

26. Aiken LH, Sloane DM, Bruynell L, Van den Heede K, Sermeus W. Nurses' report of work conditions and hospital quality of care in 12 countries in Europe. Int J Nurs Stud. 2013;50(2):143-53.

27. Griffiths P, Ball J, Drennan J, Dall'Ora C, Jones J, Maroutti A, et al. Nurse staffing and patient outcomes: strengths and limitations of the evidence to inform policy and practice. A review and discussion paper based on evidence reviewed for the National Institute for Health and Care Excellence Safe Staffing guideline development. Int J Nurs Stud. 2016;63:213-25.

28. Araújo TR, Menegueti MG, Auxiliadora-Martins M, Castilho V, Chaves LDP, Laus AM. Financial impact of nursing professional staff required in an Intensive Care Unit. Rev Latino Am Enfermagem [Internet] 2016 [cited 2016 Nov 29];24:e2818. DOI: 10.1590/1518-8345.1274.2818 